\title{
Public Information Systems and Alternative Therapeutic Approaches for Cancer in India
}

\author{
Anurag Kanaujia ${ }^{1,2}$ (D) \\ ${ }^{1}$ Academy of Scientific and Innovative Research (AcSIR), Uttar Pradesh-201002, India \\ ${ }^{2}$ Council of Scientific and Industrial Research-National Institute of Science Technology and Development \\ Studies (CSIR-NISTADS), New Delhi-110012, India
}

anuragkanaujia01@gmail.com

\section{ARTICLE INFORMATION}

Received: July 12, 2019

Revised: September 18, 2020

Accepted: September 23, 2020

Published Online: October 14, 2020

\section{Keywords:}

Complementary and Alternative Medicine, Cancer Diagnosis, Early Cancer Detection, Ayurveda, Treatment, Cancer, Rehabilitation

\section{ABSTRACT}

Background: Early detection can decrease incidences of mortality related to cancer in India. Primary tests at detection centres (generally established in urban areas and mobile facilities), need to be followed by specialized cancer centric tests. This leaves a gap for discontinuation of diagnostic process. Other factors like the prevalence of Complimentary and Alternate medicine systems (CAM), availability of mainstream healthcare services, cultural and social beliefs need to be understood for new formats for diagnosis and treatment to be devised for minimizing delay in cancer diagnosis.

Objective: This study was conducted in order:

i. To understand role of various extrinsic factors in the development of cancer diagnostics and reason for adoption of CAM treatment strategies. And,

ii. To develop a holistic understanding of these factors and their role in influencing delay in diagnosis of cancer in the Indian population.

Methods: Through comprehensive analysis from a systems point of view, problems with systemic, economical, technological and socio-cultural factors emerged as reasons for slow development in the fight against cancer. Existing diagnostic and awareness dissemination networks are also analyzed for their strengths and weaknesses. Case studies on problems in early detection of cancer have pinned cognitive barriers like attitude, social practices and information to be the primary cause for low detection rates and high mortality. Interestingly, many studies point at "people's attitude towards the disease" as a major bottleneck in adoption of mainstream medicine treatment.

Results: This paper presents a review of multiple studies about factors influencing cancer diagnostics and treatment in India. Incorporating these factors, some postulates of a nascent model for development and recalibration of cancer diagnostic network are proposed. Cancer diagnostics involves tackling preconceived notions about cancer, challenging established sociocultural systems and reshaping social practices and people's lifestyle. Public outreach programs (like camps, community events, ASHA workers and celebrity brand ambassadors) can be effective in changing attitudes in rural areas.

Conclusions: CAM therapies are a group of traditional and modern medical practices that offer a pantheon of opportunities, however they can be dangerous to patients' health if not used wisely. We support the suggestions made by other authors that an approach in integrative oncology may be effective for utilizing best of mainstream and complementary cancer treatment practices.

\section{Introduction}

Cancer is a major cause of deaths in India and worldwide. It is often associated with the changing lifestyle and environment variable, a result of technological progress in ways of production and delivery of goods and services. Reports have quoted oncologists in the country saying cancer is one of the top causes of death due to lifestyle, food habits, stress life and other factors (Anand et al., 2008; Badwe et al., 2014). A well-established healthcare diagnostic chain 'Quest diagnostics' has been quoted saying that the number of cancer cases in India will rise (Business line, 2014). An increase in number of cancer patients from 1.45 million new cases of cancer in 2016 , to 1.73 million 
in 2030 is expected. From 736,000 recorded deaths in 2016 the number is expected to rise up to 880,000 deaths by 2020 (Sharma, 2016). More than 50 percent of the diagnosed patients are unable to recover from the disease (Pal \& Mittal, 2004).

Table 1 below shows a comparison of survival rate after 5 years of diagnosis and treatment in India and other countries. The data presented in the table highlights the lack of equitable access to early diagnosis and optimal treatment in India. Out of the total incidences of cancer, about 70\% are caused by exposure to "preventable risk factors" (Julka \& Sarin, 2018) such as tobacco and co-infection (Human Papilloma Virus which causes cervical cancer). Cancer experts from major cancer care centers across the country have repeatedly expressed consent with the belief that there is a need for serious expansion in the number and quality of government run cancer care centers across the country.

Table 1: Comparison of average survival rate of the patient post five years of the detection of different cancers (Verma, 2014), (Bailey, 2014).

\begin{tabular}{|l|l|l|}
\hline \multirow{2}{*}{ Type of Cancer } & \multicolumn{2}{|l|}{$\begin{array}{l}\text { Average Survival Rate } \\
\text { (5 year after diagnosis) }\end{array}$} \\
\cline { 2 - 3 } & India & Other countries \\
\hline Stomach & $19 \%$ & $25-30 \%$ \\
\hline Colon & $37 \%$ & $50-59 \%$ \\
\hline Liver & $4 \%$ & $10-20 \%$ \\
\hline Lung & $10 \%$ & $10-20 \%$ \\
\hline Breast \& Prostate & $60 \%$ & $>80 \%$ \\
\hline Ovarian & $14 \%$ & - \\
\hline Cervical & $46 \%$ & $50 \%$ \\
\hline Leukemia & $6 \%$ & $50-60 \%$ \\
\hline
\end{tabular}

In India cancer is the second most common cause of death after cardiovascular disease (Julka \& Sarin, 2018). Being a lifestyle disease any incidence of disease is especially harsh on the poor. As the treatment of cancer in private facilities is very expensive, many patients from economically weaker section of the society are rendered broke and helpless or even worse, indebted to local financers in wake of treatment.

The director of national cancer registry program, Bangalore emphasized in an interview that patients do not (or cannot) fully comply with the treatment decided by doctors, a poor follow up is also a reason for high mortality. $\mathrm{He}$ and other experts underline that lack of awareness about the nature of disease and the need for periodic checkups and several other socio-economic factors could contribute to the low survival rates in India (Verma, 2014). Regional public hospitals are not equipped with facilities towards cancer screening for early detection. In most of the cases the diagnosis is done at very later stages of the disease, early detection is a very important factor to help reduce mortality due to cancer. Individuals with family history of cancer incidence are generally advised to undergo regular screening for cancer (Julka \& Sarin, 2018).

The Indian cancer society has estimated that only $22 \%$ of people live at least 5 years after being diagnosed with stage IV breast cancer. In case of breast cancer in India, only $27 \%$ patients diagnosed in early stages and survived 11 years or more on an average after detection and treatment. Rest $73 \%$ who are diagnosed late or advanced stages were able to survive 1-2.5 years only (Bailey, 2014). 1 out of 8 women in USA are diagnosed with cancer vs. 1 out of 22 women diagnosed in India. But as opposed to USA's 79$85 \%$ survival after diagnosis, in India the survival rate is only $60 \%$. Equitable access to early diagnosis and optimal treatment is not available. The general level of fear associated with getting the disease, poverty and ignorance towards the different symptoms of cancer are the factors that contribute to delayed diagnosis and treatment. The level of access to chemotherapy in the rural areas is very poor, even the cheaper generic versions of chemotherapy are inaccessible in rural areas contributing to high rates of mortality.

Experts Cancer registers are very important as data availability is the most prominent roadblock in presenting a valid picture of the disease. Cancer registers can serve as crucial guiding documents for policy makers in designing a rational cancer policy. In order to publish food data on regular basis political support, operational stability, adequate finance and staffing are some of the factors that need to be ensured to the cancer registers.

The lack of facilities is so because of shortage of "realistic data" on cancer prevalence in the country. The Indian cancer society has time and again emphasized on the need for making cancer a notifiable disease so as to enable collection of data on disease prevalence and infrastructure requirement.

\section{Cancer Detection, Treatment and Care}

Cancer detection in India is among the countries at lower end of the spectrum of detection efficiency. In India majority $(75 \%$ to $80 \%)$ of cancer patients are diagnosed at late stage of the disease and are thus very poor survival rates are observed (Broom et al., 2009). The difference in the detection efficiency is visible in the comparison of cancer patients surviving after detection of a malignant cancer. In developed countries approximately $50 \%$ of patients are able to recover from malignant stages, whereas 


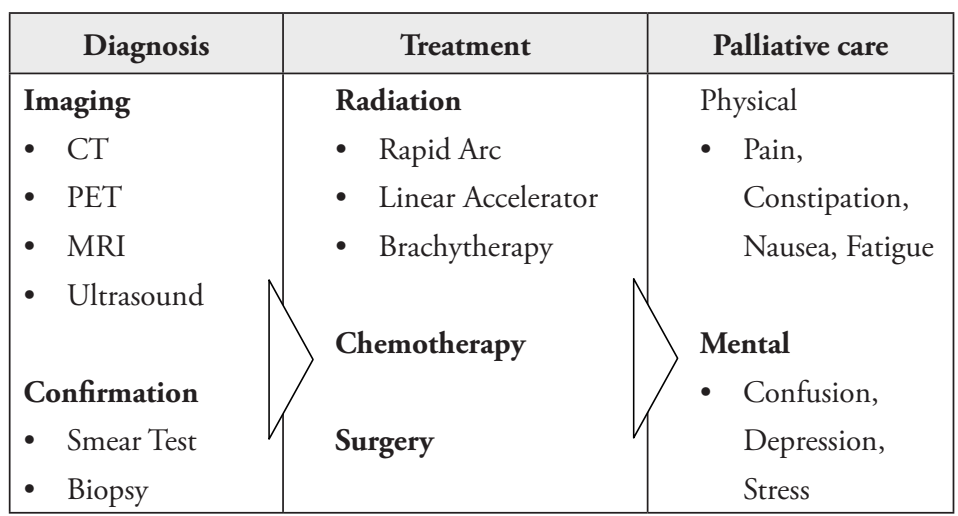

Figure 1: Common Cancer Treatment and Care Techniques. (Source: Cancer Society Finland, 2017)

in developing countries, only about $20 \%$ of cancer patients survive after detection of a malignant cancer (Pal \& Mittal, 2004).

\subsection{Cancer Specific Centers Across India}

Presently there are 12 national organizations and 6 cancer centers in India dealing with cancer research and care services and policy. Indian Cancer Society (1951), Cancer Aid and Research Foundation (CARF), Cancer Patients Aid Association (CPAA, 1969) are the main NGOs with a nationwide network for helping patients with treatments and promoting awareness among the people.

Association of Gynecologic Oncologists of India (AGOI, 1991), Association of Radiation Oncologists of India (1992), Indian Association of Surgical Oncology (IASO, 1975), Indian Cooperative Oncology Network (ICON, 1999) are the Professional associations functioning on a national scale to create platforms for oncologists to interact and collaborate.

India National Cancer Registry Programme (1981) of Indian Council of Medical Research (1CMR), Union for International Cancer Control (UICC) member Organizations: India, World Health Organization (WHO) India are the institutions with government affiliations that are involved in status measurement, policy decisions and research promotion in the country.

Dedicated cancer treatment facilities are Cancer Hospital and Research institute, Gwalior (1977), Chittaranjan National Cancer Institute, Kolkata (CNCI, 1950), Delhi State Cancer Institute (DSCI), Gujarat Cancer \& Research Institute (GCRI, 1971), Jawaharlal Institute of Postgraduate Medical Education \& Research, Puducherry (JIPMER, 2002) and Regional Cancer Centre, Thiruvananthapuram (1981). These are the main comprehensive cancer centers funded or supported by state or central government (Cancer Index, 2017).
Tata Memorial Centre, Mumbai; Dr. B Borooah Cancer Institute, Guwahati; Cancer Institute Adyar, Chennai; MNJ Institute of Oncology, Hyderabad; Birla Cancer Center, SMS Medical College Hospital, Jaipur; Regional Cancer Centre, Cuttack; Regional Cancer Centre, Thiruvananthapuram are some of the other prominent cancer care centers across the country.

\subsection{Correlation between Distances among Detection Centers and Cancer Treatment Centers in India}

According Pal \& Mittal (2004) about 70\% of Indian population depends on private medical practitioners for their healthcare needs. Many among them providing healthcare in remote regions have no medical degree. In fact, a study on diagnosis of lung cancer, conducted by a cancer center found that even practicing doctors made mistakes in diagnosing cancer cases. The authors concluded that general medicine specialists and general practitioner were likely to misdiagnose cancer as tuberculosis and fail to refer their patients to higher medical centers, thus delaying the diagnosis of cancer patients by pulmonary specialists. The population belonging to poor socioeconomic strata already stricken with appalling poverty, poor hygiene and complex social dynamics are at higher risks in such a system. In the developing world where most of the patients when diagnosed have cancer disease progressed into late stage the survival rates tend to dip significantly in comparison to the developed countries (Pal \& Mittal, 2004).

\subsection{Complementary and Alternate Medicine (CAM) Systems}

The Term "Complementary and Alternative Medicine" has evolved over time. The term CAM is supposed to have been 
accepted when the National Institute of Health's (NIH) Office of Alternative Medicine was renamed to National Center for Complementary and Alternative Medicine (NCCAM) in 1999 (Cassileth \& Deng, 2004). CAM encompasses a wide range of treatment modalities, including dietary and vitamin supplements, mind-body approaches, acupuncture, and herbal medicines (NCCIH, 2017). The biggest challenge in checking the efficacy of CAM is that there is very few or no data generated by the clinical trials on the instance of disease recurrence, survival, overall quality of life or safety. The primary justification for CAM is based on empirical evidence, case studies, and hypothetical physiological effects (Cassileth \& Deng, 2004). The acceptance and value of CAMs is very high around the globe. These medicines are easily accessible to people in regions where the penetration of mainstream medicine is low (World Health Organization, 2014). A study in Africa reported a ratio of 1:500 traditional healers in comparison with $1: 40,000$ medical doctors (Abdullahi, 2011). A study conducted with the doctors and interns at a tertiary care hospital found that majority of doctors believed that use of CAM had associated disadvantages like minimum training and qualification of traditional medicine practitioners, lack of scientific evidence in favor of CAM therapies, possibility of toxicity in the medicinal components used, unreliable diagnostic techniques which were developed with an inferior understanding of human physiology and inappropriate dose calculations in general (Roy et al., 2015).

1. Complimentary therapies are used as supportive medicines in order to control symptoms such as pain and enhance the quality of life. Complementary treatment is used along with the conventional medicines. When oncologists suggests some complementary therapies that are proven safe and effective to their patients, these complimentary therapies can become parts of mainstream oncology personifying the integrative oncology approach. This has been formalized by the renaming of NCCAM in 2015, the center is now called National Centre for Complimentary and Integrative Health (NCCIH).

2. Alternative medicine are remedies that are used for replacing mainstream treatment with conventional medicines. Alternative therapies usually claim to be self-sufficient and thus can delay mainstream treatment. Chemicals used in alternative treatments can be more harmful than chemotherapy, surgery and radiation (Cassileth \& Deng, 2004).

\section{CAM in Cancer Therapy}

In the case of cancer therapy the objectives of CAM treatments include reduction of therapy-associated toxicity, improvement of cancer-related symptoms, fostering of the immune system and even direct anticancer effects. There are various studies available that point towards the rise in use of CAM treatments among patients in western countries (Gerber et al., 2006). However, in India Even with the programme on AYUSH in place there are only limited studies that have been conducted in this field. The objectives of CAM treatments are diverse and include reduction of therapy-associated toxicity, improvement of cancer-related symptoms, fostering of the immune system and even direct anticancer effects.

Studies have highlighted spiritual healing or prayer, herbal medicine, and chiropractic therapies as most commonly used therapies in United States (Ni et al., 2002). The adoption of CAM has been rising in US and UK since 2000s. Incidentally, in a move to promote CAM research a number of medical colleges had incorporated CAM in their medical training programs. While complementary treatments do fine with mainstream cancer treatment because most of these include procedures that decrease pain and counter side-effects of chemotherapy, alternative treatments create risks with delay in treatment which reduce chances of remission and cure. Chemicals used for alternative medicines may even be potentially harmful and costly for the patients (Narayana et al., 2017).

\section{Systems of CAM}

The most well accepted classification of CAM therapies is provided by NCCAM. CAM therapies are classified into five categories: alternative/traditional medical systems, mind-body interventions, biologically based therapies, manipulative and body-based methods, and energy therapies. There are many approaches that have been discredited by mainstream literature. Some of the therapies in these categories are discussed below.

\section{Traditional Medical Systems}

All separate civilizations had a major traditional medicine system. These systems are well defined in their theory and practice and are still used widely in the regions of their origin. Prominent examples include traditional Chinese medicine (TCM), India's Ayurveda, homeopathy, and naturopathic medicine (Cassileth, 1998). An emphasis on achieving a harmonic state of mind and body using internal natural forces is the underlying feature of these systems. Many of the underlying assumptions in these systems do not have concurrence with the current scientific understanding of diseases and body physiology. Many authors treat traditional medicines and CAM as different, but this study has not differentiated between these. Consequently, the findings 
and observations of such authors are discussed in the context appropriately suited for this study.

\section{Traditional Chinese Medicine (TCM)}

Chinese medicine is written form which treats human body as a miniature ecosystem. The ecosystem consists of opposing forces which include yin-yang, heat-cold, dampness-dryness, and the circulation of Chi or Qi, meaning life energy or vital force. Maintaining the balance and the flow of these "life elements," is essential to the maintenance or restoration of health. When the body's abilities are disturbed it is in diseased condition. Disease treatment or health restoration is done by diet, nutrition, homeopathy, acupuncture, herbal medicine, hydrotherapy, spinal and soft tissue manipulation, physical therapies, therapeutic counseling and pharmacology (Tabish, 2008).

Basic philosophy is holistic care in which any illness is created as a result of imbalance between opposing forces in this ecosystem. These imbalances can be diagnosed by examining complexion and tongue coating, detecting abnormal scents in bodily materials, and palpation of the radial pulse for its speed and tactile characteristics. Any imbalance or disruptions in "life elements" from specific patterns is treated with herbal formulas or acupuncture. The Chinese medicine system consists of well characterized preparations using hundreds of botanical, animal and mineral products as ingredients. Researchers have started repurposing the biologically active compounds found in these preparations for the treatment of many other ailments including cancer. Among anticancer agents, camptothecin, paclitaxel, vincristine, and indirubin are developed from Camptotheca acuminata, Taxus chinensis, Catharanthus roseus, and Baphicacanthus cusia, respectively, although the original plants were not used traditionally to treat cancer (Zhang, 2002).

\section{Ayurveda}

The origin of the name Ayurveda is in the Sanskrit language, which was used in the Indian subcontinent during the period when this system of healthcare was developed. The words ayur and veda of which it is composed of mean life and knowledge implicating the meaning to this word, knowledge of life. It classifies human bodies into three predominant body types which have different characteristics. Based on these body types Specific remedies for disease, and regimens to promote health, are recommended. This medical system stresses on the need to keep consciousness in balance as it believes that a healthy mind can only reside in a healthy body. It uses techniques such as yoga and meditation to do balance the consciousness. Ayurveda also emphasizes regular detoxification and cleansing through all bodily orifices (Cassileth \& Deng, 2004).

\section{Homeopathy}

This system originated in the 18 th century in Germany. The main concepts under this system are similia principle which means that "like cures like"; vigorous shaking of a substance to extract its vital essence and, the concept of "potentiation," or serial dilution of extracts to achieve a low concentration of active ingredients. The highly diluted substances derived from plants, mineral or animals are used to stimulate body's own healing process. The mainstream literature discredits the principle of extreme dilution of active ingredients in homeopathy, eventually leading to concentrations of less than one molecule of the original substance meaning that there is nothing in the solution. Memorial Sloan Kettering Cancer Institute website (accessed on July 03, 2018) however has highlighted that certain homeopathic products have been observed in studies to provide long-term relief from symptoms such as headache and allergic rhinitis in adults, and atopic dermatitis and recurrent infections in children. While other reviews and analyses of homeopathy clinical trials have shown no definitive proof that homeopathic remedies are effective for any medical condition (Ernst, 2002; Cucherat et al., 2000; Linda et al., 1997).

\section{Naturopathy}

It is an alternative system that relies exclusively on "natural" healing approaches (such as herbs, nutrition, and movement or manipulation of the body). The basic belief under this system is that the body is capable of repairing and recovering from illness. The essential condition for this to happen is achievement of healthy internal environment. Common remedies in naturopathy are mistletoe, saw palmetto, red clover, wheat grass, and flax seed oil.

Table 2: Therapies under Complementary and Alternate Medicine (CAM).

\begin{tabular}{|l|l|l|l|}
\hline \multirow{2}{*}{$\begin{array}{l}\text { Medicine } \\
\text { System }\end{array}$} & \multicolumn{3}{|c|}{ Properties } \\
\cline { 2 - 4 } & Philosophy & $\begin{array}{l}\text { Treatment } \\
\text { Principle }\end{array}$ & $\begin{array}{l}\text { Treatment } \\
\text { Method }\end{array}$ \\
\hline $\begin{array}{l}\text { Traditional } \\
\text { Chinese }\end{array}$ & Qi or Chi & $\begin{array}{l}\text { Internal Natural } \\
\text { Forces }\end{array}$ & $\begin{array}{l}\text { Herbs and } \\
\text { Pressure }\end{array}$ \\
\hline Ayurveda & $\begin{array}{l}\text { Knowledge } \\
\text { of Life }\end{array}$ & $\begin{array}{l}\text { Body Type } \\
\text { Based }\end{array}$ & $\begin{array}{l}\text { Yoga and } \\
\text { Detox }\end{array}$ \\
\hline Homeopathy & $\begin{array}{l}\text { Like cures } \\
\text { Like }\end{array}$ & $\begin{array}{l}\text { Body's Healing } \\
\text { Process }\end{array}$ & $\begin{array}{l}\text { Dilute Vital } \\
\text { Essence }\end{array}$ \\
\hline Naturopathy & $\begin{array}{l}\text { Natural } \\
\text { Healing }\end{array}$ & $\begin{array}{l}\text { Internal } \\
\text { Environment }\end{array}$ & $\begin{array}{l}\text { Herbs and } \\
\text { Nutrients }\end{array}$ \\
\hline
\end{tabular}




\section{Questionable Alternative Therapies}

\section{Diet and Vitamin Cancer "Cures"}

It is one of the very popular therapy in the United States and Mexico, with most of the practitioners based in Mexico. These therapies are based on the belief that fruits, vegetables and fibers have protective effects as well as curative properties. Common treatment regimens include low-salt, high-potassium diet, coffee enemas, and a gallon of fruit and vegetable juice daily. A Japanese philosopher developed a macrobiotic diet which emphasized on whole grains, legumes, fresh vegetables, and the occasional intake of fish by integrating the traditional oriental medicine, Christian teachings, and aspects of Western medicine (CA: Clinicians., 1989; Kushi et al., 2001). Linus Pauling's proposal for treatment of disease with large quantities of nutrients known as "orthomolecular" gained a lot of attention in late 80 's and 90's but his claims that massive doses of vitamin C could cure cancer were not confirmed by clinical trials either (Moertel et al., 1985; Creagan et al., 1979).

\section{Energy Therapies}

These include techniques such as Quingong (therapeutic touch), application of electromagnetic fields to alter the energy fields around human body. The disease can be eliminated by healers who can remove any blockages to patient's energy field or by applying pulsed, alternating or direct current and magnetic fields to treat medical conditions. However, the existence of such energy fields is yet to be proven scientifically, many health practitioners in USA and other countries provide such services for various ailments including cancer (O'Mathuna, 2000; Cassileth \& Deng, 2004).

\section{Biologic Treatments}

This is a group of alternate treatments that employ invasive techniques and injection of biologically active substances in the patient's body. As a result of this invasiveness these methods of treatment carry higher risks for the patients. Some popular examples are Antineoplatons, Immunoaugmentation therapy (IAT), shark cartilage as a cancer therapy, Laetrile, bioresonance therapy, oxygen and ozone therapies, insulin potentiation therapy, and many more. Many of these are promoted as literal alternatives to mainstream cancer treatment and their user base keeps on changing (Cassileth \& Deng, 2004).

\section{Dietary Supplements and Herbal Remedies}

With the recent push to nutraceuticals and the already ongoing trend of over the counter dietary supplement in the market, patients have a choice to go for them despite being under mainstream care (Gratus et al., 2009). Dietary supplements such as vitamins, antioxidants, and herbs are used by patients of cancer (Pierce et al., 2002) Many of these popular dietary supplements used by cancer patients have been shown to have components known to show herb-drug interactions in oncology literature (Cassileth \& Lucarelli, 2003; Bhadra et al., 2015). Although in the India, any dietary supplement or nutraceutical requires license from the food safety and standards authority of India (FSSAI), these do not have to follow the same level of testing as the prescription drugs.

Many formulations are popular among general public that use herbs known to contain biologically active compounds. These include garlic, ginger, ginkgo, turmeric, mistletoe, mushrooms, etc. Some of the complementary medicine supplements which have been shown to help with improvements in the quality of life of cancer patients are, Essiac (burdock, turkey rhubarb, sorrel, and slippery elm) popular in USA as a cancer treatment; Iscador, a derivative of mistletoe, a popular cancer remedy in Europe (Kienle et al., 2003), several mushroom-derived compounds approved for use as cancer treatments in Japan, Polysaccharide Kureha (PSK), an extract of the mushroom Coriolus versicolor, showed to have superior survival in gastrectomy (Niimoto et al., 1988; Nakazato et al., 1994) and esophagectomy (Ogoshi et al., 1995) and PCS-SPES, is combination of eight herbs, all but two from TCM, which showed reduced prostate-specific antigen levels in men (Small et al., 2000).

\section{Helpful Complementary Therapies}

Most of the helpful Complementary therapies aim at helping patients cope with symptoms of diseases and counteract the side-effects of mainstream medicines. Mind-body interventions such as Hypnosis, Yoga and other relaxation techniques; Music therapy, Massage therapy, Acupuncture etc. are some of the widely used complementary therapies in cancer treatment.

Conventional practitioners use these as palliative care methods for patients. Hypnosis and Yoga aim to utilize the correlation between body and mind to help patients. These have clear benefits in reducing stress, and relieve complications caused by cancer and cancer treatments. Procedural and malignant pain (JAMA, 1996; Sellick \& Zara, 1998), anxiety, depression, and mood in newly diagnosed cancer patients (Bindemann et al., 1991; Walker et al., 1999), chemotherapyinduced nausea in adults (Vasterling et al., 1993; Morrow \& Morrell, 1982; Raghavendra et al., 2007)), are usually treated with these complementary therapies.

Music therapy is used as a palliative care measure and has benefits in anxiety (Kwekkeboom, 2003), depression 
(Burns, 2001), and pain (Zimmerman et al., 1989) for patients as well as their family members. In US and Europe, music therapy is taught as a graduate degree course and professional musicians are trained as music therapists, while in India such courses are not offered.

Massage therapy is useful in reducing anxiety, at least in the short-term nausea, and fatigue and improving general well-being (Grealish et al., 2000). It is a part of many traditional medicine systems and widely accepted as a helpful method of patient care across the world.

Acupuncture believes that stimulation of certain points in the body regulates the flow of Qi through these points. These points are present along the "meridians" of the body and are stimulated using needles, pressure, heat, electric pulses or laser. The most well accepted explanation for the effect of acupuncture is that the stimulation of these points can cause release of neurotransmitters leading to the feeling of relief in the patients (Han, 2003).

\section{Case Studies}

The use of CAM has been identified by Indian oncologists as a potential factor for the delay in seeking help from medical practitioners but no research has been conducted to verify such claims. The rural Indian population relies heavily on the use of traditional indigenous systems of medicine. These thousands of years old systems are well known among the rural population and they are confident about the efficacy of these practices. Ayurveda, Unani and Siddha are among the most widely practiced systems of medicine in India (Ministry of AYUSH, 2018). Following section consists of short descriptions of case studies in India about the use of CAM therapies among the patients of cancer. Table 3 presents a list of the studies conducted across India and compares the estimates on the percentage of CAM users in these studies.

Chaturvedi et al., (2002) is the earliest case study available about the use of CAM among the cancer patients. In this study, the investigators sampled 550 cancer patients in Delhi for the use of CAM therapies. This study found that $38 \%$ of the sampled cancer patients used CAM therapies at one point or other, further among women the use of these therapies was more common when compared to men. The study also pointed out that women patients showed varying delays in seeking biomedical treatment (Chaturvedi et al., 2002).

Another early study on use of CAM therapies came out in Lancet Oncology in 2002. The investigator had interviewed cancer patients or their caregivers. All the patients were using an alternative cancer therapy called Psorinum. It is a combination of homeopathy and natural medicines along with conventional supportive care. The results of this study showed that most of the users were urban residents (85\%). Although this might be because of the location of the care center, which was located in an urban metropolis. More than half of the patients were elderly individuals. The reasons given by the patients for opting the alternative therapy are provided in Table 3.

Broom et al., (2009) surveyed 825 cancer patients in one public and one private hospital in Delhi to identify patterns of seeking professional medical help. A significant proportion of the sampled population, $34.3 \%$ of cancer patients had used CAM. Most commonly used CAM was Ayurveda, which the authors have classified as Traditional system. The "socio-demographic" profiles of CAM users suggested that they were generally older married private patients, belonging to upper caste Hindu families. The users of CAM therapies were residents of nearby regions as compared to those patients who did not use CAM therapies. Interestingly the type of cancer a patient was suffering from, also had correlation with the use of CAM. Patients with solid tumor were statistically more likely to be CAM users compared to those with haematological malignancies. Further, CAM users were statistically more likely to have metastatic or advanced disease compared with non-users. The user of CAM was more likely to delay consulting a doctor in case of complications whereas patients who did not use CAM immediately consulted the

Table 3: Available case studies on patients using CAM in treatment of cancer.

\begin{tabular}{|l|l|l|l|l|l|l|}
\hline & City & Cancer & Year & $\begin{array}{l}\text { Participants } \\
\text { (Number) }\end{array}$ & $\begin{array}{l}\text { \%age } \\
\text { CAM user }\end{array}$ & Reason for Choosing CAM \\
\hline 1. & Delhi, India & All & 2002 & 550 & 38 & $\begin{array}{l}\text { Family and Friends recommended for using other available } \\
\text { options }\end{array}$ \\
\hline 2. & Kolkata, India & All & 2002 & 200 & 100 & $\begin{array}{l}\text { No other treatment option, financial constraint, better quality of } \\
\text { life for old or terminal patients }\end{array}$ \\
\hline 3. & Delhi. India & All & 2009 & 825 & 34 & $\begin{array}{l}\text { Suggestions from Internet and Family members, Previous use of } \\
\text { CAM therapies }\end{array}$ \\
\hline
\end{tabular}

(Sources: Chaturvedi et al., 2002; Pal, 2002; Broom et al., 2009) 
doctor for a diagnosis and treatment (Broom et al., 2009). These findings resonate with the claims made by other studies and throws light on the social distribution of CAM users. However, economic and geographic distribution still remains unexplored.

\section{Preconceived Notions About Cancer}

The 2012 WHO report on use of CAM highlights that based on the economic, cultural and social factors prevalent in the region the medicinal use varies between countries. Countries with very well established modern health care systems can have high percentages of their populations using CAM systems. Singapore and Korea, are countries where health care systems are quite well established, still $76 \%$ and $86 \%$ of their population use TCM (World Health Organization, 2012). The prevalent notions about cancer in India should also be understood with social, cultural and economic background of the country. The economic variability and cultural diversity of the regions must play a role in people's choice of treatment method. Low socioeconomic status, illiteracy and accessibility of health services are some of the prominent factors that have been associated with presentation of cancer to clinics at advanced stages. Earlier studies have also claimed that many times a patient chooses CAM because they do not have any other option available to them (Pal, 2002). Table 4 below presents a summary of studies showing positive effects for patients using CAM.

CAM therapies are considered to be more effective and safer by the patients using them. The medicines from traditional systems are generally less costly and easily available in comparison to allopathic medicines in certain regions. Surveys that studied use of CAM therapies found that these are used commonly by both doctors and patients. However, it is seen that there is a lack of communication between doctors and patients regarding the use of CAM therapies. This gap is presumably a result of the perception that doctors discredit the use of CAM by their patients in most of the cases (Bauer, 2000; Furlow et al., 2008). It has been proposed for long time that the communication about use of CAM can be improved by sensitization of doctors and inclusion of CAM in the medical curriculum. Table 5 below lists the studies conducted in India among the doctors and patients. These studies were carried out in various regions and aimed to quantify individual perceptions about CAM therapies.

Earlier studies from USA suggested that younger individuals with higher education and higher socioeconomic status seek CAM therapies (Cassileth \& Deng, 2004). This pattern slightly modified in the observations of the studies conducted in India where older married individuals from better socio-economic background were more likely to use CAM (Pal, 2002; Broom et al., 2009). Although, the finding that women are more likely to choose CAM therapies is also seen in India. This validates the explanation that people higher education and higher socioeconomic status are more health conscious and utilize more mainstream medical services than do people who do not use CAM. There is some indication of growth in CAM use by cancer patients in recent years (Cassileth \& Deng, 2004).

A review of literature from 15 countries on the use of CAM therapies showed that the use of these therapeutic systems across these countries varied from $9.8 \%$ to $76 \%$ (Harris et al., 2012). The East Asian countries scored high on the use of CAM in-spite of having well developed mainstream healthcare systems. Adults were more frequent users of CAM than children. Physicians have varying beliefs regarding the efficacy of CAM, studies from India listed in (table 5) above and previous surveys from other parts shown these variations in physicians' beliefs and practices of CAM. (Furlow et al., 2008; Milden \& Stokols, 2004; Bauer, 2000).

In India CAM is still not a part of conventional medical curriculum in medical colleges. However, the Government of India has recognized the prevalence of CAM systems in India and the ministry of AYUSH has taken steps for

Table 4: Case studies showing positive results of CAM therapies.

\begin{tabular}{|l|l|l|l|l|l|}
\hline S.No. & Issue Addressed & Therapy & Year & Participants & Effect \\
\hline 1. & Pain and Anxiety & Spa & 2018 & Patients 52 & Decrease in issues \\
\hline 2. & Neck, shoulder and upper arm pain & $\begin{array}{l}\text { chiropractic, osteopathy } \\
\text { and physiotherapy }\end{array}$ & 2012 & $\begin{array}{l}\text { Healthcare service } \\
\text { providers 448 }\end{array}$ & Relief from pain \\
\hline 3. & Nausea and emesis & Yoga & 2007 & $\begin{array}{l}\text { Chemo receiving } \\
\text { patients 62 }\end{array}$ & $\begin{array}{l}\text { Significant decrease } \\
\text { in symptoms }\end{array}$ \\
\hline 4 & $\begin{array}{l}\text { Hospital Anxiety and Depression } \\
\text { Scale (HADS), Perceived Stress } \\
\text { Scale (PSS) and DNA damage }\end{array}$ & Yoga & $\begin{array}{l}\text { Radiotherapy } \\
\text { receiving patients 68 }\end{array}$ & $\begin{array}{l}\text { Modulated stress and } \\
\text { DNA damage levels }\end{array}$ \\
\hline
\end{tabular}

(Sources: Skaczkowski et al., 2018; Denyer et al., 2012; Raghavendra et al., 2007; Banerjee et al., 2007) 
Table 5: Studies on perception of users about CAM therapies.

\begin{tabular}{|c|c|c|c|c|}
\hline Title & Author & Year & Target Group & \% Perception \\
\hline $\begin{array}{l}\text { Use and satisfaction of complementary } \\
\text { and alternative medicine among diabetic } \\
\text { patients in a tertiary care hospital }\end{array}$ & $\begin{array}{l}\text { Monica N., Jayanthi } \\
\text { CR, Praveen } \\
\text { Panchaksharimath }\end{array}$ & 2018 & $\begin{array}{l}200 \text { patients at a diabetic } \\
\text { clinic }\end{array}$ & Overall $29 \%$ accept use \\
\hline $\begin{array}{l}\text { Prevalence of the use of complementary and } \\
\text { alternative medicine in an eastern Indian } \\
\text { population with emphasis on tribal/ethnic } \\
\text { minority groups }\end{array}$ & $\begin{array}{l}\text { Jayanti Ray, Debadatta } \\
\text { Chakrabarty, Rudrajit } \\
\text { Paul, Kunal Som }\end{array}$ & 2018 & $\begin{array}{l}\text { Adult patients at urban } \\
\text { university hospital and a } \\
\text { rural hospital in east India }\end{array}$ & $\begin{array}{l}\text { Time since use } \\
36.7 \% \text { - 1 year } \\
57.2 \% \text { - lifetime } \\
\text { Mostly Tribal people used. }\end{array}$ \\
\hline $\begin{array}{l}\text { Awareness, practice and views about } \\
\text { integrating AYUSH in allopathic } \\
\text { curriculum of allopathic doctors and interns } \\
\text { in a tertiary care teaching hospital in New } \\
\text { Delhi, India }\end{array}$ & $\begin{array}{l}\text { Shubha Singhal, } \\
\text { Vandana Roy }\end{array}$ & 2018 & $\begin{array}{l}\text { Allopathic Doctors and } \\
\text { Interns }\end{array}$ & Overall $46.7 \%$ accept use \\
\hline $\begin{array}{l}\text { Complementary and alternative medicine } \\
\text { use among type } 2 \text { diabetes patients in a } \\
\text { tertiary care hospital }\end{array}$ & $\begin{array}{l}\text { Shamiya Sadiq, } \\
\text { Kanika Khajuria, Vijay } \\
\text { Khajuria }\end{array}$ & 2017 & $\begin{array}{l}\text { Diabetic patients attending } \\
\text { OPD of Government } \\
\text { medical college hospital }\end{array}$ & $\begin{array}{l}\text { Females } 56.36 \% \\
\text { Educated } 90.90 \%\end{array}$ \\
\hline $\begin{array}{l}\text { Doctors perception on integrated medicine: } \\
\text { A survey }\end{array}$ & $\begin{array}{l}\text { Sarala Narayana, } \\
\text { Asha Basavareddy, } \\
\text { Meenakshi Lella }\end{array}$ & 2017 & $\begin{array}{l}\text { Doctors of Kolar and } \\
\text { Bangalore }\end{array}$ & Overall $57 \%$ accept use \\
\hline $\begin{array}{l}\text { Complementary and alternative medicine } \\
\text { use in medical OPD patients of rheumatoid } \\
\text { arthritis in a tertiary care hospital }\end{array}$ & $\begin{array}{l}\text { Shamiya Sadiq, } \\
\text { Sharminder Kaur, } \\
\text { Vijay Khajuria, Sapna } \\
\text { Gupta, Aman Sharma }\end{array}$ & 2016 & $\begin{array}{l}\text { Patients having } \\
\text { rheumatoid arthritis } \\
\text { reporting to medical OPD } \\
\text { of tertiary-care } \\
\text { hospital }\end{array}$ & $\begin{array}{l}\text { Overall 60-80\% accept } \\
\text { use }\end{array}$ \\
\hline $\begin{array}{l}\text { Perception, attitude and usage of } \\
\text { complementary and alternative medicine } \\
\text { among doctors and patients in a tertiary } \\
\text { care hospital in India }\end{array}$ & $\begin{array}{l}\text { V Roy, M Gupta, RK } \\
\text { Ghosh }\end{array}$ & 2015 & $\begin{array}{l}\text { Doctors working at a } \\
\text { tertiary care teaching } \\
\text { hospital }\end{array}$ & $\begin{array}{l}\text { Doctors } 58 \% \\
\text { Patients } 28 \% \text { accept use }\end{array}$ \\
\hline $\begin{array}{l}\text { Knowledge, attitude and practice of } \\
\text { complementary and alternative medicines } \\
\text { for diabetes }\end{array}$ & $\begin{array}{l}\text { D. Kumar, S. Bajaj R. } \\
\text { Mehrotra }\end{array}$ & 2006 & $\begin{array}{l}\text { Patients with diabetes } \\
\text { attending the clinic for } \\
\text { the first time at Endocrine } \\
\text { clinic of Swaroop } \\
\text { Rani, Nehru Hospital, } \\
\text { Allahabad, India. }\end{array}$ & $\begin{array}{l}\text { Overall } 67 \% \text { accept use } \\
\text { Desire for quick and } \\
\text { additional relief was the } \\
\text { most common perceived } \\
\text { reason for using CAM }\end{array}$ \\
\hline $\begin{array}{l}\text { Pattern of use of complementary/ alternative } \\
\text { medicine (CAM) in epileptic patients in a } \\
\text { tertiary care hospital in India }\end{array}$ & $\begin{array}{l}\text { M. Tandon, S. } \\
\text { Prabhakar, P. Pandhi }\end{array}$ & 2002 & $\begin{array}{l}\text { Patients with seizure } \\
\text { disorder visiting the } \\
\text { Neurology outpatient } \\
\text { department }\end{array}$ & $\begin{array}{l}\text { All } 32 \% \\
\text { Rural } 67 \% \\
\text { Sought CAM providers } \\
\text { first before seeking the } \\
\text { services of a medical } \\
\text { doctors }\end{array}$ \\
\hline $\begin{array}{l}\text { Prevalence and pattern of use of } \\
\text { complementary and alternative medicine } \\
\text { (CAM) in hypertensive patients of a tertiary } \\
\text { care center in India. }\end{array}$ & $\begin{array}{l}\text { Shafiq N, Gupta M, } \\
\text { Kumari S, Pandhi P }\end{array}$ & 2003 & $\begin{array}{l}\text { Patients visiting } \\
\text { Hypertension Clinic at the } \\
\text { PGIMER, Chandigarh }\end{array}$ & $\begin{array}{l}\text { Overall } 63.9 \% \text { accept use } \\
\text { Fear of adverse drug } \\
\text { reactions of conventional } \\
\text { medicines }\end{array}$ \\
\hline $\begin{array}{l}\text { Patterns and perceptions of complementary } \\
\text { and alternative medicine (CAM) among } \\
\text { leukaemia patients visiting haematology } \\
\text { clinic of a north Indian tertiary care hospital }\end{array}$ & $\begin{array}{l}\text { M. Gupta, N. Shafiq, } \\
\text { S. Kumari, P. Pandhi }\end{array}$ & 2002 & $\begin{array}{l}\text { Leukaemia patients } \\
\text { visiting Haematology } \\
\text { clinic of a North Indian } \\
\text { tertiary care hospital }\end{array}$ & $\begin{array}{l}\text { Overall } 56.6 \% \text { accept use } \\
\text { Patients sought } \\
\text { mainstream medicine } \\
\text { first, followed by CAM } \\
\text { therapies }\end{array}$ \\
\hline
\end{tabular}


easy availability of CAM including the Indian systems of medicine. Difficulty in accessing limited literature on CAM has been attributed as one of the reasons for lack of awareness among medical graduates. Studies on the attitude and perception of patients and doctors about utilizing CAM services for cancer treatment and care are very limited in India. These studies can be useful since practitioners of modern medicines have to encounter patients using CAM (Roy et al., 2015).

\section{Answering the Research Questions}

\subsection{Reasons and Factors Cited for Choosing CAM}

This study has been conducted to understand the reasons which motivate patients suffering from Cancer to adopt of CAM treatment strategies in India. This research question has been answered using an extensive literature survey. Case studies that dealt with this topic were reviewed and the reasons that were found in these studies were categorized. Main factors for individuals choosing to adopt CAM include Education, Health status, orientation towards health practices, Cultural background, financial constraints etc. Individuals with higher education and superior social status were more likely to choose CAM therapies during the treatment of cancer. Dissatisfaction or inability of mainstream medical treatment in contributing towards the betterment of the patient's condition lead to patient opting a CAM treatment regimen (Bahall, 2017). Patients also claimed that they had more personal autonomy and control over healthcare decisions when using alternative treatment methods (Pal, 2002). Many Indian as well as foreign studies claimed Compatibility of practiced CAM therapy with patient's values, worldview $\&$ belief regarding nature and meaning of health \& illness. Also, individuals who had used CAM earlier and had experienced success with alternative therapy in a minor ailment have been observed to inclined to using CAM for cancer treatment as well.

\subsection{The Various Extrinsic Factors in the Development of Cancer Diagnostics}

\subsubsection{High Cost of Healthcare Services}

The cost of healthcare for a cancer patient are very high and exhaustive for the patients. From diagnosis to treatment and palliative care during and after the treatment are influenced by multiple factors. According to Pramesh et al., 2014, cancer is a major test of health-care systems in developing countries especially because of their socio-economic background. The public health spending per person is among the lowest in India when compared to other countries of the world. Even with increasing rate of overall public expenditure, access and delivery of basic cancer care to all the patients across India remains a farfetched challenge (Prachitha \& Shanmugam, 2012). In India, the healthcare spending patterns vary substantially across states. State health systems deliver variably on their aim of cost effective and affordable services to all the residents. As a result, a migration of patients from one state to other is seen, with the motivation to seek better healthcare. Cancer patients are especially vulnerable to high out of pocket expenditure leading to financial emergencies in their families. Despite an on-par cancer specific expenditure in the world, insufficient Infrastructure, manpower shortages, lack of cross-state solutions for prevention and early detection of cancer are the characteristics of Indian cancer diagnosis and care system. The largely unregulated private sector, high cost of new technologies and drugs for cancer treatment increase the burden on the patients. In this setup there is a need to improve quality of care and deliver cost effective cancer care programs (Pramesh et al., 2014).

\subsubsection{Evaluations of Existing System and Inputs for its Strengthening}

In cancer awareness, research and service delivery, Indian Cancer Society has played an important role. Cancer awareness camps at schools, colleges and workplaces provide essential information regarding symptoms of cancer diseases. Appeals of celebrity brand ambassadors through mass media and at community programs (cyclothons, walkathons etc.) have huge potential for changing perceptions and attitude towards the disease (CPAA- Awareness and Early Cancer detection, 2016). It is a strong makeshift structure that has contributed its bit to tackle issue of inadequate infrastructure by conducting early detection camps using mobile detection vans as well as facilitating research and learning activities through its cancer registry system. (ICS- Raise against cancer, TOI, 2015). Public outreach programs (like camps, community events, ASHA workers and celebrity brand ambassadors) can be effective in changing attitudes in rural areas.

This field involves multiple factors (like awareness, use of proprietary technologies, difficulties in evaluation, accessibility etc.) that need to be understood. The poor provision of public sector healthcare means many people (even the poor) turn to the private sector.

\subsubsection{New Developments in Diagnosis Methods}

Early diagnosis is crucial in cancer care, however the detection is delayed due to cumbersome diagnosis procedures. The availability of infrastructure in rural and remote areas is another cause for delay in the presentation of disease to the medical practitioners. There are many new technologies 
that are promising to address this gap in cancer diagnosis. Following are four Indian startups that using cutting edge imaging and artificial intelligence are working in developing solutions for efficient and easy detection of cancer.

These and many other technological interventions are being developed by innovators in the country. Most of these technologies are attempted towards addressing infrastructural and human resources bottlenecks such as poor doctor to patient ratio, affordable diagnosis laboratories, technologies available for rural implementation, delay in diagnostic results etc. The founders of these startups have expressed that the aim for these technologies is early detection of cancer. Artificial Intelligence and Machine learning algorithms have been heavily employed in these technologies to quickly and efficiently analyze the indicators of disease. Use of cloud computing has further amplified the potential impact of these technologies as experts can access the results from these tests without being present at the test site. (SigTuple, 2017; NIRAMAI Health Analytix, 2018; Aindra Systems, 2018; UE Lifesciences Inc., 2018)

\section{Socio-Economic Distribution of Patients Receiving Cancer Treatment in Government Funded Safdarjung Hospital, Delhi}

The investigator conducted interviews with cancer patients and their care givers at a government hospital in New Delhi. The hospital provides free treatment for many ailments to patients coming from different parts of the country. These patients were selected based on their availability and willingness to interact with the interviewer about their disease. The interviews were semi-structured in order to establish a comfortable rapport with the respondents. A total of 12 patients were interviewed over a course of 3 visits to the hospital in one month. The location of hospital is shown in Map 1, it is located at a very accessible location in the city and is well connected by various modes of transport like Road (InterCity and City Bus services, Private vehicles etc.), Metro Rail (Nearest Metro station is AIIMS, which is at the main gate of hospital), and Railways (Four main railway stations in Delhi namely New Delhi, Old Delhi, Hazarat Nizzamuddin and Civil Lines are well connected by road). The sampling method used can be classified as purposive convenience sampling as the investigator did not have an access to a stable documented population of patients to choose samples. The main objective of the interviews were to document the socio-economic attributes of the patients, the distribution of disease burden and the use of CAM among these patients. The results obtained from the survey are presented below. Box 1 contains, a few detailed interview transcripts for the purpose of illustration to the reader.

\section{Demographic Profile}

Out of the 12 individuals interviewed, the ratio of male and female individuals was $\sim 40: 60$. The disease was seen more among older individuals as compared to younger individuals. The religious profile as expected showed higher incidences in Hindu community which conforms to the religious distribution of the region.

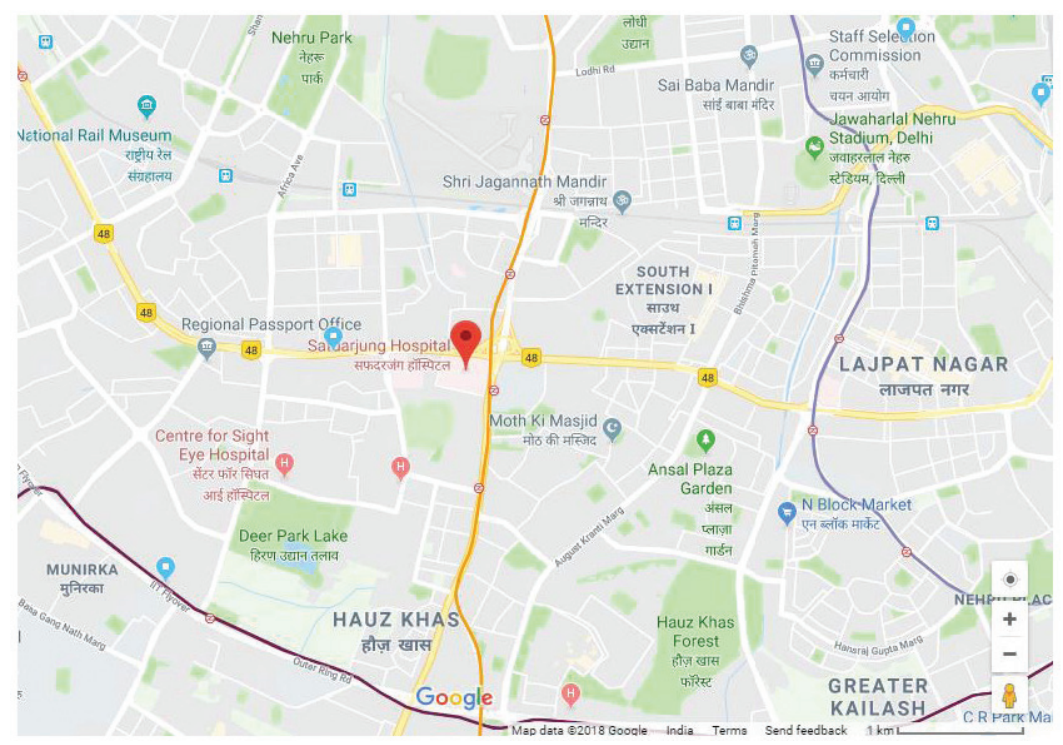

Map 1: Interview Location: Safdarjung Hospital. 


\section{Socio-Economic Profile and CAM Use}

Of the interviewed patients many belonged to economically weaker sections and hailed from villages and areas adjoining the city. Most of the individuals in the sample set were farmers and labours who had very less savings and thus were bound to come to the public hospital for their treatment. Most of them had used CAM at one point or other in an attempt to get better option for treatment. Some individuals had used these medicines in order to

\section{Box 1: Safdarjung - Ovarian Cancer - Wife and Husband Age in late 60s - Migrated for treatment from village to New Delhi (Interview transcript) (Source- Author)}

We are here for treatment of my wife's cancer. She has cancer in her stomach. We have been living on the hospital premises for last 6 years. We are from Bihar where we have our house. Our children are living in our village home. I was a farmer before, but now I have to be with her and our children have to look after our fields. They send us money for staying here, we have to stay here because of the regime of medications (chemotherapy) and the distance between Delhi and our village does not allow us to travel frequently. These days we stay here for 3 weeks at a stretch and go back to our village for 1 week. Earlier it used to be every week without any gap so we had to stay here for longer durations.

We have to make do with whatever arrangements are there in the hospital in all the seasons. When it rains all the people living here come and take shelter below the shades so it gets very crowded. In winter people distribute blankets and some temporary shelters are also raised in the hospital. There is a shelter home near the AIIMS trauma center in which only relatives of patients in the trauma center are allowed to stay.

Doctors do not care where we are staying, they are only concerned about their responsibility that timely treatment is administered to the patient.

We have to buy food from the hospital canteen which is reasonably cheap, and one plate is enough for both of us. Canteen staff knows us now and they send our food to us regularly. On days when my wife has chemotherapy, hospital provides food free of charge. We use hospital bathrooms.

We consulted in AIIMS, Safdarjung and other hospitals in Bihar, Lucknow as well. In AIIMS the treatment cost is to be borne by the patient which is too much for us. While in Safdarjung the samples were sent to 3-4 hospitals for diagnosis to decide on the course of treatment. Here everything is free of cost, this is a major factor that we have decided to continue her treatment here. Although there is no improvement but the disease is also not progressing so we have decided to stay on with this treatment.

There are cleanliness drives in the hospitals sometimes when we are asked to move to different locations, but police are understanding to our plight and we are allowed to stay here. It would have been a convenience to us if there were shelter homes for us like the AIIMS trauma center shelter but things are as they are and we don't complain.

\begin{tabular}{|c|c|c|c|}
\hline MANTHANA & NIRAMAI & AIndra Systems & UE Life Sciences \\
\hline $\begin{array}{l}\text { - An AI platform and } \\
\text { Microscopy device } \\
\text { - Visual representation of } \\
\text { the abnormality } \\
\text { - Blood test for cancerous } \\
\text { and pre-cancerous cells } \\
\text { - Hub and Spoke model: } \\
\text { pathologists can access } \\
\text { lab results anywhere } \\
\text { - Address inefficient } \\
\text { analysis of lab results }\end{array}$ & $\begin{array}{l}\text { - Non-Invasive Risk Assessment } \\
\text { with Machine Intelligence } \\
\text { - Enhanced thermal imaging to } \\
\text { detect breast cancer } \\
\text { - Contact \& Radiation free } \\
\text { scanning technology } \\
\text { - Mammography - Rs 3,500 } \\
\text { NIRAMAI - Rs 1,000 } \\
\text { - Being used in clinics, diagnostic } \\
\text { labs, rural healthcare centres, } \\
\text { and corporate camps }\end{array}$ & $\begin{array}{l}\text { - An AI Platform } \\
\text { - Analyses Pap Smear samples } \\
\text { - Classification on the basis of } \\
\text { microscopy } \\
\text { - Detect cancer at the point-of- } \\
\text { care } \\
\text { - Delays due to lab results } \\
\text { decreased } \\
\text { - Useful to patients in rural areas } \\
\text { - Report sent to pathologists for } \\
\text { action }\end{array}$ & $\begin{array}{l}\text { - iBreastExam: a non- } \\
\text { invasive, portable, painless } \\
\text { and radiation-free device } \\
\text { - High precision and } \\
\text { sensitivity for detection of } \\
\text { early signs } \\
\text { - Tactile sensors and Micro } \\
\text { sensors detect anomalies } \\
\text { up to } 3 \mathrm{~mm} \\
\text { - Usable by community } \\
\text { health workers in rural } \\
\text { locations }\end{array}$ \\
\hline
\end{tabular}

Figure 2: New Cancer Detection Techniques being Developed in India. 
address the symptoms of the disease or side effects of the hospital treatment. A correlation between use of CAM and satisfaction from mainstream treatment is hard to draw from the present data. There seemed to be a 50:50 distribution of treatment satisfaction among the cancer patients interviewed.

\begin{tabular}{|l|c|}
\hline \multicolumn{2}{|c|}{ Age Profile } \\
\hline Age (yrs.) & $\begin{array}{l}\text { No. of } \\
\text { respondents }\end{array}$ \\
\hline $30-40$ & 1 \\
\hline $40-50$ & 2 \\
\hline $50-60$ & 4 \\
\hline $60-70$ & 5 \\
\hline
\end{tabular}

\begin{tabular}{|l|c|}
\hline \multicolumn{2}{|c|}{ Gender Profile } \\
\hline Gender & $\begin{array}{l}\text { No. of } \\
\text { respondents }\end{array}$ \\
\hline Male & 5 \\
\hline Female & 7 \\
\hline Other & 0 \\
\hline
\end{tabular}

\begin{tabular}{|l|c|}
\hline \multicolumn{2}{|c|}{ Religion } \\
\hline Religion & $\begin{array}{l}\text { No. of } \\
\text { respondents }\end{array}$ \\
\hline Hindu & 7 \\
\hline Muslim & 3 \\
\hline Sikh & 1 \\
\hline Other & 1 \\
\hline
\end{tabular}

\section{Cancer Types and Diagnosis}

The distribution of cancer among the sample was also analyzed. Cancers related to tobacco use were observed to have a high occurrence rate. These were seen in male population and thus seem to be correlated to a higher prevalence of tobacco use among them. Among the female population breast and ovarian cancer were the predominant types seen with occurrences of cervical and stomach cancer as well. Many patients had no idea about the stage of disease, which indicates towards the lack of awareness even among the patients. $40 \%$ of the patients were in late or intermediate stages. Almost all of these individuals were referred to the hospital after a primary consultation with their local physicians or healthcare providers.

\begin{tabular}{|l|c|}
\hline \multicolumn{2}{|c|}{ Economic Profile } \\
\hline Occupation & $\begin{array}{l}\text { No. of } \\
\text { respondents }\end{array}$ \\
\hline Farmer & 2 \\
\hline Labour & 4 \\
\hline Service & 2 \\
\hline Self-employed & 4 \\
\hline
\end{tabular}

\begin{tabular}{|l|c|}
\hline \multicolumn{2}{|c|}{ Residence } \\
\hline Area & $\begin{array}{l}\text { No. of } \\
\text { respondents }\end{array}$ \\
\hline Village & 3 \\
\hline Adj. Town & 2 \\
\hline City & 6 \\
\hline Not fixed & 1 \\
\hline
\end{tabular}

\begin{tabular}{|l|c|}
\hline \multicolumn{2}{|c|}{ Use of CAM } \\
\hline Purpose for use & $\begin{array}{l}\text { No. of } \\
\text { respondents }\end{array}$ \\
\hline Ceased & 4 \\
\hline For Pain & 2 \\
\hline For Health & 3 \\
\hline No Used & 3 \\
\hline
\end{tabular}

\begin{tabular}{|l|l|}
\hline \multicolumn{2}{|c|}{ Treatment Satisfaction } \\
\hline $\begin{array}{l}\text { Level of } \\
\text { satisfaction }\end{array}$ & $\begin{array}{l}\text { No. of } \\
\text { respondents }\end{array}$ \\
\hline Satisfied & 6 \\
\hline Not-satisfied & 2 \\
\hline No choice & 4 \\
\hline
\end{tabular}

\begin{tabular}{|l|c|}
\hline \multicolumn{2}{|c|}{ Type of Cancer } \\
\hline Type & $\begin{array}{l}\text { No. of } \\
\text { respondents }\end{array}$ \\
\hline Breast & 2 \\
\hline Cervical & 1 \\
\hline Colon & 1 \\
\hline Oral & 3 \\
\hline Ovarian & 2 \\
\hline Stomach & 3 \\
\hline
\end{tabular}




\begin{tabular}{|l|c|}
\hline \multicolumn{2}{|c|}{ Cancer Stage } \\
\hline Stage & $\begin{array}{l}\text { No. of } \\
\text { respondents }\end{array}$ \\
\hline Early & 3 \\
\hline Intermediate & 3 \\
\hline Late & 2 \\
\hline Don't know & 4 \\
\hline
\end{tabular}

\begin{tabular}{|l|c|}
\hline \multicolumn{2}{|c|}{ Years since diagnosed } \\
\hline Years & $\begin{array}{l}\text { No. of } \\
\text { respondents }\end{array}$ \\
\hline $0-2$ & 4 \\
\hline $2-4$ & 4 \\
\hline $4-5$ & 2 \\
\hline$>5$ & 2 \\
\hline
\end{tabular}

The observation from the case study are indicative towards the continuation of trends reported in previously published studies. However, one should refrain from drawing major conclusions from this very limited study as it does not cover numerous possible scenarios. The study still points towards the possibility of further investigation on the correlation between CAM use and delay in presentation of disease to the cancer centers. It can also be observed that the public healthcare services are predominantly utilized by economically less affluent individuals and indicates towards the higher use of private healthcare facilities by the other sections of the society.

\section{Implications for Oncologists}

The availability of new diagnosis techniques will help oncologists make precise and quick assessment of disease for the patients. Additional information provided by the marriage of medical technology with artificial intelligence provides new windows of opportunity for early detection of cancer, providing quality medical advice to rural patients through information technology and addressing cultural barriers in presentation of disease to doctors especially in case of female patients.

Use of CAM by cancer patients has been observed across the globe (Burstein et al., 1999; Cassileth et al., 2001; Bernstein \& Grasso, 2001). It is imperative to promote open communication between patients and oncologists. However most of the patients that report to a cancer care center are looking for mainstream medicine to cure their condition. Besides having knowledge about CAM the oncologists have to be able to establish confidence about the treatment they offer to the patients. Unsatisfied patients continuously search for better treatments and in this attempt sometimes adopt treatments which can be hazardous. The most well established role of complementary therapies has been in managing pain, nausea, fatigue, anxiety associated with side effects of mainstream treatment and disease symptoms. Oncologists have to be aware about these ground realities for maximum success with their treatment regimens.

\section{Conclusion}

The growth of integrative medicine has added a new dimension in the use of the various contemporary medicine systems. The use of complimentary healthcare in the western world has seen unprecedented expansion in the capabilities and attitudes about treatment of chronic diseases. Integration of effective CAM therapies with mainstream treatment of diseases like cancer has changed the discourse of conversation about what is and is not "good medicine". On the other hand, use of some other therapeutic practices that challenge the basics of mainstream medicine has led to numerous questions about the efficacy of many of these (Grossoehme et al., 2009; Fulop et al., 2017).

CAM therapies offer a pantheon of opportunities for patient care and treatment of side effects to mainstream cancer treatments, however they can be dangerous to patients' health if not used wisely. An approach in integrative oncology may be effective for utilizing best of mainstream and complementary cancer treatment practices (Nahleh \& Tabbara, 2003). For development of a healthcare system that is based on the principles of integrative, inclusion of CAM therapies as part of mainstream medical education would be a logical step. This would familiarize doctors to prevalent CAM systems and better equip them to treat patients who have used of traditional medicines. If the oncologists are aware about the most popular remedies then they can have an open communication with the patients (Bhadra et al., 2015). This will promote efficient use of both systems of healthcare as oncologist will be able to find and share information about most popular remedies from reliable sources for themselves and for their patients (Nahleh \& Tabbara, 2003; Cassileth \& Deng, 2003).

An effective treatment of malignant cancers is premised upon early diagnosis and detection by a healthcare provider. In India, the presentation of cancer patients to a doctor is delayed by various reasons. These include, insufficient attention to the symptoms of disease (mostly seen in women patients), inaccessibility of detection services (remote and rural areas, and poor individuals), use of CAM (prevalent among older educated socially affluent patients), incorrect diagnosis by the physician, etc. CAM is considered to be an 
important factor related to delay in presentation of disease to a cancer center. This observation suggests that the correlation between the use of CAM and high rates of presentation of disease at advanced stages needs to be empirically established.

The second question that arises is the factors that influence individuals to choose CAM over mainstream healthcare services. Claims that the cost CAM is less than mainstream healthcare are important to observe in the specific socio-economic background of the country. Potential interactions between CAM and chemotherapy, is another issue that can only be resolved with further clinical examinations.

The ideological issues associated with CAM use incite treatment of cancer from a different and sometimes even erroneous perspectives. These issues have significant implications for cancer detection and care in India and potentially in other developing countries as well. The roles and implications of CAM usage in different disease stages can be examined in palliative and end-of-life care. (Broom et al., 2009).

\section{Acknowledgements}

The author thanks CSIR, India and NISTADS, New Delhi, where Anurag Kanaujia conducted his $\mathrm{PhD}$ research. Thanks to Ms. Antara Chakrabarty, M.A. at Centre for Informal Sector and Labour Studies, Jawaharlal Nehru University for her help with the conducting interviews of patients. Our regards and best wishes to the patients and respondents of our survey. The author also thanks Amala cancer research centre (IACR), Thrissur, Kerala, where the results from this study were presented at the 36th Annual conference of Indian Association for Cancer research.

Authorship Contribution: The study was conducted and written by Anurag Kanaujia.

Funding: The project was undertaken as an independent study, conducted without any external funding.

Conflict of Interest: Author(s) of this manuscript have no any conflicts of interest with publication of the manuscript or an institution or products used in the manuscript.

\section{References}

Abdullahi, A.A. (2011). Trends and challenges of traditional medicine in Africa. African Journal of Traditional Complementary and Alternative Medicine, 8(5S), 115123. https://doi.org/10.4314/ajtcam.v8i5S.5

Aindra Systems (2018). Aindra Systems. [Online] Available at: http://www.aindra.in/ [Accessed July 2018].
Anand, P., Kunnumakkara, A.B., Sundaram, C., Harikumar, K.B., Tharakan, S.T., Lai, O.S., Sung, B., \& Aggarwal, B.B. (2008). Cancer is a Preventable Disease that Requires Major Lifestyle Changes. Pharmaceutical Research, 25(9), 2097-2116. https://doi.org/10.1007/ s11095-008-9661-9

Anon (1989). Macrobiotic diets for the treatment of cancer. CA: A Cancer Journal of Clinicians, 39(4), 248-251. https://doi.org/10.3322/canjclin.39.4.248

Anon (1996). Integration of behavioral and relaxation approaches into the treatment of chronic pain and insomnia. NIH Technology Assessment Panel on Integration of Behavioral and Relaxation Approaches into the Treatment of Chronic Pain and Insomnia. JAMA, 276(4), 313-318. https://doi.org/10.1001/ jama.1996.03540040057033

Badwe, R.A., Dikshit, R., Laversanne, M., \& Bray, F. (2014). Cancer Incidence Trends in India. Japanese Journal of Clinical Oncology, 44(5), 401-407. https:// doi.org/10.1093/jjco/hyu040

Bahall, M. (2017). Use of complementary and alternative medicine by patients with end-stage renal disease on haemodialysis in Trinidad: A descriptive study. BMC Complementary and Alternative Medicine, 17, 250. https://doi.org/10.1186/s12906-017-1755-7.

Bailey, L. (2014). Early breast cancer diagnosis, survival rates low in rural India. s.l.: University of Michigan.

Banerjee, B., Vadiraj, H.S., Ram, A., Rao, R., Jayapal, M., Gopinath, K.S., Ramesh, B.S., Rao, N., Kumar, A., Raghuram, N., Hegde, S., Nagendra, H.R., \& Hande, M.P. (2017). Effects of an Integrated Yoga Program in Modulating Psychological Stress and Radiation-Induced Genotoxic Stress in Breast Cancer Patients Undergoing Radiotherapy. Integarative Cancer Therapies, 6(3), 242-250. https://doi. org/10.1177/1534735407306214

Bauer, B.A. (2000). Herbal therapy: What a clinician needs to know to counsel patients effectively. Mayo Clinic Proceedings, 75(8), 835-841. https://doi. org/10.4065/75.8.835

Bernstein, B.J., \& Grasso, T. (2001). Prevalence of complementary and alternative medicine use in cancer patients. Oncology (Huntington), 15(10), 1267-1272. https://doi.org/10.4066/AMJ.2015.2479

Bhadra, R., Ravakhah, K., \& Ghosh, R.K. (2015). Herbdrug interaction: The importance of communicating with primary care physicians. Australasian Medical Journal, 8(10), 315-319. https://doi.org/10.4066/ AMJ.2015.2479

Bindemann, S., Soukop, M., \& Kaye, S. (1991). Randomised controlled study of relaxation training. 
European Journal of Cancer, 27(2), 170-174. https:// doi.org/10.1016/0277-5379(91)90480-2

Bridge, L., Benson, P., Pietroni, P., \& Priest, R.G. (1998). Relaxation and imagery in the treatment of breast cancer. British Medical Journal, 297, 1169-1172. https://doi.org/10.1136/bmj.297.6657.1169

Broom, A., Nayar, K.R., Tovey, P., Shirali, R., Thakur, R., Seth, T., \& Chettri, P., (2009). Indian Cancer Patients' use of Traditional, Complementary and Alternative Medicine (TCAM) and delays in presentation to Hospital. Oman Medical Journal, 24(2), 99-102.

Burns, D.S. (2001). The effect of the bonny method of guided imagery and music on the mood and life quality of cancer patients. Journal of Music Therapy, 38(1), 5165. https://doi.org/10.1093/jmt/38.1.51

Burstein, H.J., Gelber, S., Guadagnoli, E., \& Weeks, J.C. (1999). Use of alternative medicine by women with early-stage breast cancer. New England Journal of Medicine, 340, 1733-1739. https://doi.org/10.1056/ NEJM199906033402206

Bussiness line (2014, January 07). Quest takes cancer diagnostic services pan India. The Hindu: Bussiness Line. Retrieved from https://www.thehindubusinessline. com/companies/Quest-takes-cancer-diagnosticservices-pan-India/article20708983.ece

Cancer Index (2017). Cancer Index. Retrieved from http:// www.cancerindex.org/India\#section9

Cancer Society Finland (2017). All about cancer. Retrieved from https://www.allaboutcancer.fi/facts-about-cancer/

Cassileth, B. (1998). The Alternative Medicine Handbook: The Complete Reference Guide to Alternative and Complimentary Therapies. New York: W.W. Norton \& Company Inc.

Cassileth, B., \& Lucarelli, C. (2003). Herb-Drug Interactions in Oncology. Hamilton: B.C. Decker.

Cassileth, B.R., \& Deng, G. (2004). Complementary and Alternative Therapies for Cancer. The Oncologist, 9(1), 80-89. https://doi.org/10.1634/theoncologist.9-1-80

Cassileth, B.R., Schraub, S., Robinson, E., \& Vickers, A. (2001). Alternative medicine use worldwide: The International Union Against Cancer survey. Cancer, 91(7), 1390-1393. https://doi.org/10.1002/1097$0142(20010401) 91: 7<1390$ : : A I D CNCR1143>3.0.CO;2-C

Chaturvedi, P., Chaturvedi, U., \& Sanyal, B., (2002). Alternative medicine and cancer patients in less developed countries. Lancet Oncology, 3(1), 10. https:// doi.org/10.1016/S1470-2045(01)00615-5

Creagan, E.T., Moertel, C.G., O’Fallon, J.R., Schutt, A.J., O'Connell, M.J., Rubin, J., \& Frytak, S. (1979). Failure of high-dose vitamin $\mathrm{C}$ (ascorbic acid) therapy to benefit patients with advanced cancer. A controlled trial. New England Journal of Medicine, 301, 687-690. https://doi.org/10.1056/NEJM197909273011303

Cucherat, M., Haugh, M.C., Gooch, M., Boissel, J.-P. et al. (2000). Evidence of clinical efficacy of homeopathy. A meta-analysis of clinical trials. European Journal of Clinical Pharmacology, 56, 27-33. https://doi. org/10.1007/s002280050716

Denyer, K., Smith, H., Davies, K., Horne, R., Hankins, M., \& Walker-Bone, K. (2012). A pilot study to compare the views of traditionally trained and CAMtrained therapists using the clinical exemplar of the management of neck/upper limb pain to assess barriers to effective integration of approaches. Complementary Therapies in Medicine, 20(1-2), 38-44. https://doi. org/10.1016/j.ctim.2011.10.004

Ernst, E. (2002). A systematic review of systematic reviews of homeopathy. British Journal of Clinical Pharmacology, 54(6), 577-582. https://doi.org/10.1046/j.13652125.2002.01699.x

Fulop, J.A., Grimone, A., \& Victorson, D. (2017). Restoring balance for people with cancer through integrative oncology. Primary Care: Clinics in Office Practice, 44(2), 323-335. https://doi.org/10.1016/j. pop.2017.02.009

Furlow, M.L., Patel, D.A., Sen, A., \& Liu, J.R. (2008). Physician and patient attitudes towards complementary and alternative medicine in obstetrics and gynecology. BMC Complementary and Alternative Medicine, 8, 35. https://doi.org/10.1186/1472-6882-8-35

Gerber, B., Scholz, C., Reimer, T., Briese, V., \& Janni, W. (2006). Complementary and alternative therapeutic approaches in patients with early breast cancer: A systematic review. Breast Cancer Research and Treatment, 95(3), 199-209. https://doi.org/10.1007/ s10549-005-9005-y

Gratus, C., Wilson, S., Greenfield, S.M., Damery, S.L., Warmington, S.A., Grieve, R., Steven, N.M., \& Routledge, P. (2009). The use of herbal medicines by people with cancer: a qualitative study. $B M C$ Complimentary and Alternative Medicine, 9, 14. https://doi.org/10.1186/1472-6882-9-14

Grealish, L., Lomasney, A., \& Whiteman, B. (2000). Foot massage. A nursing intervention to modify the distressing symptoms of pain and nausea in patients hospitalized with cancer. Cancer Nursing, 23(3), 237-243. https:// doi.org/10.1097/00002820-200006000-00012

Grossoehme, D.H., Ragsdale, J., Dixon, C., Berz, K., \& Zimmer, M. (2009). The Changing Face of Medical Education: The Role of Religion, Integrative. The Open Medical Education Journal, 2, 80-87.

Han, J. (2003). Acupuncture: neuropeptide release produced by electrical stimulation of different frequencies. 
Trends in Neurosciences, 26(1), 17-22. https://doi. org/10.1016/S0166-2236(02)00006-1

Harris, P.E., Copper, K.L., Relton, C., \& Thomas, K.J. (2012). Prevalence of complementary and alternative medicine (CAM) use by the general population: A systematic review and update. International Journal of Clinical Practice, 66(10), 924-939. https://doi. org/10.1111/j.1742-1241.2012.02945.x

Julka, D.P.K., \& Sarin, D.R. (2018). Disease not a death warrant and is mostly treatable, say experts. The Times of India, 18 January.

Kienle, G.S., Berrino, F., Bussing, A., Portalupi, E., Rosenzweig, S., \& Kiene, H. (2003). Mistletoe in cancer-a systematic review on controlled clinical trials. European Journal of Medical Research, 8(3), 109-119.

Kumar, D., Goel, N.K., Pandey, A.K., \& Sarpal, S.S. (2016). Complementary and alternative medicine use among the cancer patients in Northern India. South Asian Journal of Cancer, 5(1), 8-11. https://doi. org/10.4103/2278-330X.179689

Kushi, L.H., Cunningham, J.E., Hebert, J.R., Lerman, R.H., Bandera, E.V., \& Teas, J. (2001). The macrobiotic diet in cancer. Journal of Nutrition, 131, 3056S-3064S. https://doi.org/10.1093/jn/131.11.3056S

Kwekkeboom, K.L. (2003). Music versus distraction for procedural pain and anxiety in patients with cancer. Oncology Nursing Forum, 30(3), 433-440. https://doi. org/10.1188/03.ONF.433-440

Linda, K., Clausius, N., Ramirez, G., Melchart, D., Eitel, F., Hedges, L.V., \& Jonas, W.B. (1997). Are the clinical effects of homeopathy placebo effects? A meta-analysis of placebo-controlled trials. Lancet, 350(9081), 834-843. https://doi.org/10.1016/ S0140-6736(97)02293-9

Milden, S.P, \& Stokols, D. (2004). Physicians' attitudes and practices regarding complementary and alternative medicine. Behavioural Medicine, 30, 73-82. https:// doi.org/10.3200/BMED.30.2.73-84

Ministry of AYUSH (2018). Ministry of Ayurveda, Yoga and Naturopathy, Unani, Siddha and Homeopathy (AYUSH). Retreived from http://ayush.gov.in/aboutthe-systems

Moertel, C.G., Fleming T.R., Creagan, E.T., Rubin, J., O'Conell, M.J., \& Ames, M.M. (1985). High-dose vitamin Cversus placeboin the treatment of patientswith advanced cancer who have had no prior chemotherapy. A randomized double-blind comparison. New England Journal of Medicine, 312, 137-141. https://doi. org/10.1056/NEJM198501173120301

Morrow, G.R., \& Morrell, C. (1982). Behavioral treatment for the anticipatory nausea and vomiting induced by cancer chemotherapy. New England Journal of Medicine, 307, 1476-1480. https://doi.org/10.1056/ NEJM198212093072402

Nahleh, Z., \& Tabbara, I. (2003). Complementary and alternative medicine in breast cancer patients. Palliative and Supportive Care, 1(3), 267-273. https:// doi.org/10.1017/S1478951503030256

Naja, F., Anouti, B., Shatila, H., Akel, R., Haibe, Y., \& Tfayli, A. (2017). Prevalence and Correlates of Complementary and Alternative Medicine Use among Patients with Lung Cancer: A Cross-Sectional Study in Beirut, Lebanon. Evidence based complimentary and alternate medicine, 2017, 8434697. https://doi. org/10.1155/2017/8434697

Naja, F., Fadel, R.A., Alameddine, M., Aridi, Y., Zarif, A., Hariri, D., Mugharbel, A., Khalil, M., Nahleh, Z., \& Tfayli, A. (2015). Complementary and alternative medicine use and its association with quality of life among Lebanese breast cancer patients: A crosssectional study. BMC complimentary and alternative medicine, 15, 444. https://doi.org/10.1186/s12906015-0969-9

Nakazato, H., Koike, A., Saji, S., Ogawa, N., Sakamoto, J., \& Nakazato, H. (1994). Efficacy of immunochemotherapy as adjuvant treatment after curative resection of gastric cancer. Study Group of Immunochemotherapy with PSK for Gastric Cancer. Lancet, 343(8906), 1122-1126. https://doi. org/10.1016/S0140-6736(94)90233-X

Narayana, S., Basavareddy, A., \& Lella, M. (2017). Doctors perception on integrated medicine: A survey. Journal of Basic Clinical Pharmacology, 8, 62-65.

NCCIH (2017). Complementary, Alternative, or Integrative Health: What's In a Name?. Retreived from https:// nccih.nih.gov/health/integrative-health

Ni, H., Simile, C., \& Hardy, A.M. (2002). Utilization of complementary and alternative medicine used by United States adults: results from 1999 national health interview survey. Medical Care, 40(4), 353-358. https:// doi.org/10.1097/00005650-200204000-00011

Niimoto, M., Hattori, T., Tamada, R., Sugimachi, K., Inokuchi, K., \& Ogawa, N. (1988). Postoperative adjuvant immunochemotherapy with mitomycin C, futraful and PSK for gastric cancer. An analysis of data on 579 patients followed for five years. The Japanese Journal of Surgery, 18, 681-686. https://doi. org/10.1007/BF02471530

NIRAMAI Health Analytix (2018). NIRAMAI. Retreived from http://niramai.com/

Ogoshi, K., Satou, H., Isono, K., Mitomi, T., \& Endoh, M. (1995). Immunotherapy for esophageal cancer. A 
randomized trial in combination with radiotherapy and radiochemotherapy. American Journal of Clinical Oncology, 18(3), 216-222. https://doi. org/10.1097/00000421-199506000-00007

O'Mathuna, D.P. (2000). Evidence-based practice and reviews of therapeutic touch. Journal of Nursing Scholarship, 32(3), 279-285. https://doi.org/10.1111/ j.1547-5069.2000.00279.x

Pal, S.K. (2002). Use of alternative cancer medicine in India. Lancet Oncology, 3, 394-395.

Pal, S.K. \& Mittal, B. (2004). Fight Against Cancer in Countries with Limited Resources: The Post-genomic Era Scenario. Asian Pacific Journal of Cancer Prevention, 5, 328-334.

Pierce, J.P. et al. (2002). A randomized trial of the effect of a plant-based dietary pattern on additional breast cancer events and survival: The Women's Healthy Eating and Living (WHEL) Study. Controlled Clinical Trials, 23(6), 728-756. https://doi.org/10.1016/S01972456(02)00241-6

Prachitha, J. \& Shanmugam, K. (2012). Efficiency of raising health outcomes in Indian states. Working paper $70 / 2012$

Pramesh, C.S. et al. (2014). Delivery of affordable and equitable cancer care in India. Lancet Oncology, 15(6), E223-E233. https://doi.org/10.1016/S14702045(14)70117-2

Raghavendra, R., Nagarathna, R., Nagendra, H.R., Gopoinath, K.S., Srinath, B.S., Ravi, B.D., Patil, S., Ramesh, B.S., Nalini, R. (2007). Effects of an integrated yoga programme on chemotherapy-induced nausea and emesis in breast cancer patients. European Journal of Cancer Care, 16(6), 462-474. https://doi. org/10.1111/j.1365-2354.2006.00739.x

Roy, V., Gupta, M., \& Ghosh, R.K. (2015). Perception, attitude and usage of complementary and alternative medicine among doctors and patients in a tertiary care hospital in India. Indian Journal of Pharmacolology, 47(2), 137-142. https://doi.org/10.4103/0253-7613.153418

Sellick, S. \& Zara, C. (1998). Critical review of 5 nonpharmacologic strategies for managing cancer pain. Cancer Prevention and Control, 2(1), 7-14.

Sharma, D.C. (2016). Cancer data in India show new patterns. The Lancet Oncology, 17(7), E272. https:// doi.org/10.1016/S1470-2045(16)30202-9

Shukla, Y. \& Pal, S.K. (2004). Complementary and Alternative Cancer Therapies: Past, Present and the Future Scenario. Asian Pacific Journal of Cancer Prevention, 5(1), 3-14.
SigTuple (2017). SigTuple. Retreived from https://sigtuple. com/blog/manthana/

Skaczkowski, G., Moran, J., Langridge, J., Oataway, K., \& Wilson, C. (2018). Effect of a spa bath on patient symptoms in an acute palliative care setting: A pilot study. Complementary Therapies in Clinical Practice, 32, 100-102. https://doi.org/10.1016/j.ctcp.2018.05.004

Small, E.J., Frohlich, M.W., Bok, R., Shinohara, K., Grossfeld, G., Rozenblat, Z., Kelly, K., Corry, M., \& Reese, D.M. (2000). Prospective trial of the herbal supplement PCSPES in patients with progressive prostate cancer. Journal of Clinical Oncology, 18(21), 3595-3603. https://doi.org/10.1200/JCO.2000.18.21.3595

Soper, S.A. (2006). Point-of-care biosenson systems for cancer diagnostics/prognostics. Biosensors and Bioelectronics, 21(10), 1932-1942. https://doi. org/10.1016/j.bios.2006.01.006

Tabish, S.A., (2008). Complementary and Alternative Healthcare: Is It Evidence-based?. International Journal of Health Sciences, 2(2), 5-9.

Times of India; Indian Cancer Society (2016, May 15). Rise against Cancer. Times of India.

UE Lifesciences Inc. (2018). UE Lifesciences Inc. Retreived from http://www.uelifesciences.com/

Vasterling, J., Jenkins, R.A., Tope, D.M. \& Burish, T.D. (1993). Cognitive distraction and relaxation training for the control of side effects due to cancer chemotherapy. Journal of Behavioral Medicine, 16, 6580. https://doi.org/10.1007/BF00844755

Verma, S. (2014, December 07). Cancer Survival rate in India among the lowest in the world. Times of India. Retreived from https://health.economictimes. indiatimes.com/news/industry/cancer-survival-ratein-india-among-the-lowest-in-the-world/45400655

Walker, L., Walker, M.B., Ogston, K., Heys, S.D., Ah-See, A.K., Miller, I.D., Hutcheon, A.W., Sarkar, T.K., \& Eremin, O. (1999). Psychological, clinical and pathological effects of relaxation training and guided imagery during primary chemotherapy. British Journal of Cancer, 80, 262-268. https://doi.org/10.1038/ sj.bjc. 6690349

Zhang, J.T. (2002). New drugs derived from medicinal plants. Therapie, 57(2), 137-150.

Zimmerman, L., Pozehl, B., Duncan, K., \& Schmitz, R. (1989). Effects of music in patients who had chronic cancerpain. Western JournalofNursingResearch, 11, 298309. https://doi.org/10.1177/019394598901100304 


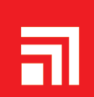 \\ CHITKARA}

Journal of Multidisciplinary Research in Healthcare

Chitkara University, Saraswati Kendra, SCO 160-161, Sector 9-C, Chandigarh, 160009, India

Volume 7, Issue 1

October 2020

ISSN 2393-8536

Copyright: [@ 2020 Anurag Kanaujia] This is an Open Access article published in Journal of Multidisciplinary Research in Healthcare (J. Multidiscip. Res. Healthcare) by Chitkara University Publications. It is published with a Creative Commons Attribution- CC-BY 4.0 International License. This license permits unrestricted use, distribution, and reproduction in any medium, provided the original author and source are credited. 